\title{
THE COMMERCIAL AND DISCARD CATCH RATES OF THE TRAWL FISHERY IN THE İSKENDERUN BAY (NORTHEASTERN LEVANTINE SEA)
}

\author{
Cem DALYAN \\ İstanbul University, Faculty of Science, Depertment of Biology, Vezneciler, İstanbul, TURKEY \\ Cite this article as: \\ Dalyan C. 2020. The Commercial and Discard Catch Rates of the Trawl Fishery in the İskenderun Bay (Northeastern Levantine Sea). Trakya Univ J Nat Sci, \\ 21(2): 123-129, DOI: 10.23902/trkjnat.773435
}

Received: 24 July 2020, Accepted: 18 September 2020, Online First: 01 October 2020, Published: 15 October 2020

Edited by:

Herdem Aslan

\section{Corresponding Author:}

Cem Dalyan

cdalyan@istanbul.edu.tr

\section{ORCID ID:}

orcid.org/0000-0002-7386-5641

Key words:

Discard

Landed Catch

Turkey

Levantine Sea

Fish species

\begin{abstract}
The management of fishery is significant due to the sustainability of marine resources. Therefore, the fishing areas should be constantly monitored. In this study, the fishery data were collected from the Iskenderun Bay (Northeastern Levantine Sea) with a rented commercial trawl vessel. The fishery-dependent data was recorded during the 2012-2013 fishing season with the help of the crew. 33 tows were achieved using a trawl net (codend diamond mesh size of $44 \mathrm{~mm}$ ) for 26 hours. Each tow was limited with 70 min and the towing speed varied between 2.5 to 3.0 knots. The depth contour ranged from 39 to $69 \mathrm{~m}$. While 32 species were evaluated as discard, 35 species were included in the landed catch. The total catch consisted of $67.2 \%$ the landed and $32.8 \%$ of the discarded fish in terms of CPUEw (catch per unit effort by weight).
\end{abstract}

Özet: Deniz kaynaklarının sürdürülebilirliği için balıkçılık yönetimi son derece önemlidir. Bu nedenle balıkçılık alanları sürekli olarak izlenmelidir. Bu çalışmada kullanılan veriler İskenderun Körfezi'nde (Kuzeydoğu Levant Denizi) avlanan bir ticari trol teknesi ile toplanmıştır. Balıkçıllğa bağlı veriler, 2012-2013 balıkçılık sezonunda tekne mürettebat yardımı ile kaydedilmiştir. 26 saat süren 33 trol çekimi $44 \mathrm{~mm}$ rombik ağ gözü boyutuna sahip torba kullanılarak gerçekleştirilmiştir. Trol çekim hızı 2,5 ila 3,0 knot arasında değişmiş ve en fazla 70 dakika sürmüştür. İskenderun Körfezi'nde 39-69 m derinlik konturu incelenmiştir. 32 tür 1skarta olarak değerlendirilirken, 35 tür ticari av içinde yer almıștır. Buna karşın, toplam av CPUEw (birim zamanda elde edilen biyokütle) açısından değerlendirildiğinde \%67,2'sinin ticari ava \%32,8'inin ise 1skarta ait olduğu saptanmıştır.

\section{Introduction}

Discard is a part of the catch that is unwanted by fishers due to being too small, damaged, inedible, having a little or no economic value, or not being able to be retained with management or quota restrictions (Zeller et al. 2018). Data on discard rates plays a key role for understanding the energy flow of the marine ecosystem (Machias et al. 2001).

The bottom trawl makes the highest contribution to the 9.1 million tonnes annual discard levels worldwide with 4.2 million tonnes (Pérez Roda et al. 2019). Mitigation of discard catches is extremely decisive on biodiversity and ecosystem health. There are some ways like mesh size regulations, catch quotas or effort limitations, minimum landing sizes to reduce the amount of discard catch caught by trawls (Weissenberger 2014). In Turkish waters, the mesh size and minimum landing size regulations are preferred by the Ministry of Agriculture and Forestry.

Researchers performed so far in Turkish Seas have focused on discard catch in the last few decades and most of them used beam trawls (Bayhan et al. 2006, Demirci
2003, Gökçe \& Metin 2006, Kınacıgil 1999a, b, Soykan et al. 2006, Yazic1 et al. 2006). However, conducting a long-term monitoring study to determine the discarded yield takes too much effort and it is financially compelling as well.

The present study was conducted in the Iskenderun Bay (Easternmost Levantine Sea) where a high biodiversity is present. Erythrean invasion is one of the main causes of this situation. Invasion is also the most important ecological process affecting fisheries in northeastern Mediterranean Sea. The Red Sea immigrants are evaluated in trawl catch from the Northeastern Levantine Sea (Gücü et al. 1994, Gücü et al. 2010, Özyurt et al. 2018, Yemişken et al. 2014). Apart from this, the bay hosts many cartilaginous fishes and these fishes were previously investigated in terms of bycatch and discard. However, the majority of Elasmobranch species are threatened with extinction in the area (Yağlıoğlu et al. 2015, Yemişken et al. 2014).

This study aimed to define the catch composition and catch/discard rates of trawl fisheries in Iskenderun Bay. 


\section{Materials and Methods}

\section{Study Area}

The Northeastern Levantine Sea has a wide continental shelf including the Iskenderun Bay (Fig. 1). The bay is preferred as a study area due to being an important fishing area in the Eastern Mediterranean (Yemisken et al. 2014). Its surface area is about $2275 \mathrm{~km}^{2}$ with an average depth of $70 \mathrm{~m}$, and its bottom is mainly covered with sand and mud. The range of sea surface water temperature was recorded between 16 and $30^{\circ} \mathrm{C}$ during 2012-2013 (Karpuz \& Sakalli 2019) while salinity varied from 37.0 to 39.4 psu (Terbıyık Kurt 2018).

The regulations and restrictions of trawl fishery are determined by the Ministry of Agriculture and Forestry. The fishing season in the Iskenderun Bay is between September 15 and April 15 every year. Fishing in the bay is prohibited within the first 2 miles off the coast and 44 $\mathrm{mm}$ minimum mesh size for the diamond mesh can be used in the Turkish coasts of the Mediterranean Sea.

\section{Sampling}

Fishery dependent data were collected by the commercial trawler (Faik Baba, $22 \mathrm{~m}, 400 \mathrm{HP}$ ), in December 2012, February and April 2013, during the legal fishing season. 33 tows with trawl net had achieved with a codend diamond mesh size of $44 \mathrm{~mm}$. Each towing duration ranged from 30 to $70 \mathrm{~min}$ depending on topology, bottom type and vessel speed and the towing speed varied between 2.5 to 3.0 knots.

Fieldwork included recording the characteristics of the haul, the estimation of the total catch and landed catch. When the catch reached to the board, it was sorted out as commercial and discard by the crew. After the catch was sorted by the crew, the discard portion was put in boxes. Then the number of individuals of the discard catch was counted and the total weights of each species were noted. Weight was determined to the nearest $1 \mathrm{~g}$. Sub-sampling was performed for the species with a high number of individuals. Species that are difficult to identify were identified in the laboratory.

\section{Statistical Analysis}

The most reliable estimation used to determine negative or positive changes in stocks, is the CPUE (Catch Per Unit Effort) calculation (Bordalo-Machado 2006). The CPUE of the trawl was calculated and expressed as biomass/towing time or abundance/towing time (Eq. 1) (D’Onghia et al. 2003, Morgan \& Burges 2005).

Eq. $1 \quad \mathrm{CPUE}_{\mathrm{W}}=\mathrm{Cw} / \mathrm{t}$ and $\mathrm{CPUE}_{\mathrm{A}}=\mathrm{C}_{\mathrm{A}} / \mathrm{t}$

$\mathrm{Cw}$ : Biomass of the catch $(\mathrm{g})$

CA: Abundance of the catch (ind)

$\mathrm{t}$ : Towing time $(\mathrm{h})$

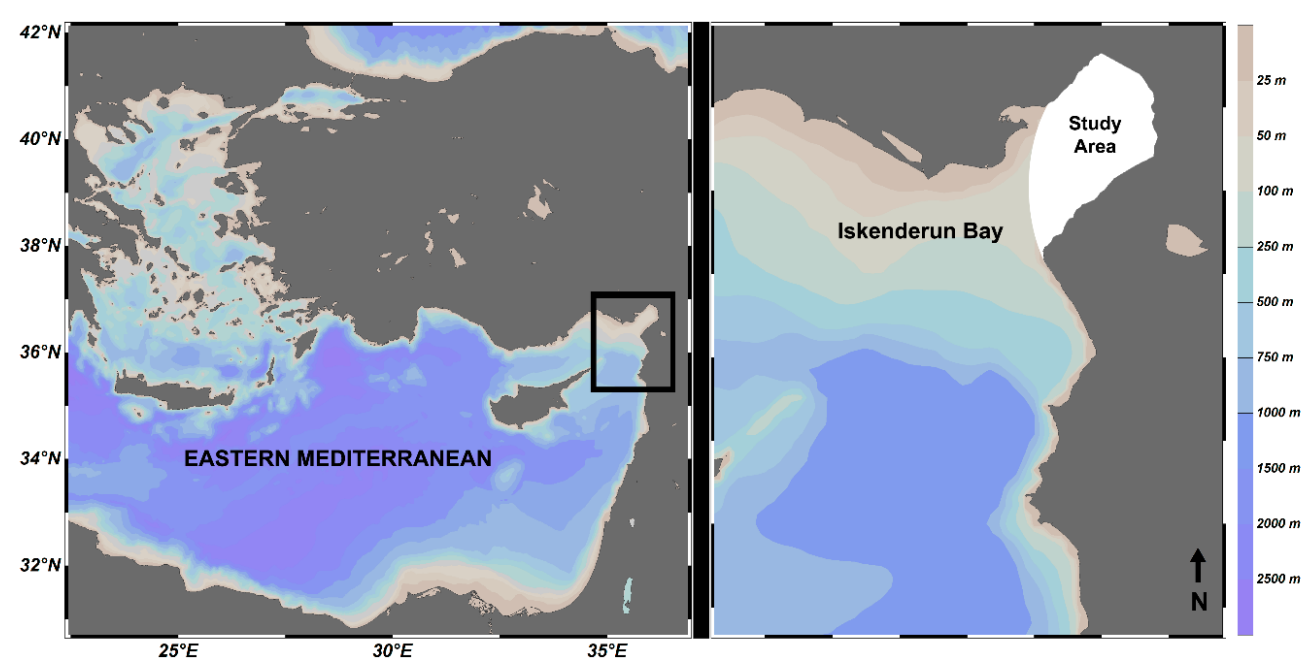

Fig. 1. Sampling area in the Iskenderun Bay, Northeastern Levantine Sea.

\section{Results and Discussion}

The tows duration lasted 26 hours in 33 tows (Table 1). The tows were performed at 39-69 m (average depths) depth contour, which is the most visited by fishermen in fishing seasons. Among the tows, the highest abundance and biomass values belonged to the haul at $39 \mathrm{~m}$, which is the shallowest depth. While the discard catch per haul was estimated between 0.25 and $25.5 \mathrm{~kg} / \mathrm{h}$, total fish catch varied between 2.3 and $41 \mathrm{~kg} / \mathrm{h}$ during the fishing period (Table 1).

In 2012-2013 fishing season, a total of 67 species were evaluated by the crew, of which 32 were in discard and 35 were in the landed catch. Glaucostegus cemiculus (Geoffroy St. Hilaire, 1817), Mustelus mustelus (Linnaeus, 1758) and Zeus faber Linnaeus, 1758 were placed in discard catch due to avoided sizes of the individuals.

A total of $332 \mathrm{~kg}$ of the catch was obtained during the study. The total abundance of fishes was 7738. Data refers to 10506 individuals when the number of individuals in each tow is standardized by the swept area $\left(\mathrm{CPUE}_{\mathrm{A}}\right)$, $60.5 \%$ of which are discarded (Table 2). In terms of $\mathrm{CPUE}_{\mathrm{W}}$ the trawl catches mainly consisted of $67.2 \%$ landed and $32.8 \%$ discarded fish. 
Table 1. The informative data of the tows achieved in the Iskenderun Bay at 2012-2013 fishing season (Tow numbers 1-12 were carried out in Dec-2012, 13-25 in Feb-2013 and 26-33 in Apr-2013).

\begin{tabular}{|c|c|c|c|c|c|c|}
\hline Tows & $\begin{array}{c}\text { Average } \\
\text { Depth (m) }\end{array}$ & $\begin{array}{c}\text { Towing Time } \\
\text { (h) }\end{array}$ & $\begin{array}{c}\text { Landed } \\
\left(\mathrm{CPUE}_{\mathrm{A}}\right)(\mathrm{ind} / \mathrm{h})\end{array}$ & $\begin{array}{c}\text { Landed } \\
(\text { CPUEw) (g/h) }\end{array}$ & $\begin{array}{c}\text { Discard } \\
\left(\text { CPUE }_{A}\right)(\text { ind/h) }\end{array}$ & $\begin{array}{c}\text { Discard } \\
\text { (CPUEw) }(\mathrm{g} / \mathrm{h})\end{array}$ \\
\hline 1 & 61 & 1.17 & 72 & 12228.2 & 182 & 3031.6 \\
\hline 2 & 56 & 1.00 & 173 & 9323.0 & 149 & 5719.3 \\
\hline 3 & 39 & 0.33 & 1060 & 21569.7 & 348 & 19416.0 \\
\hline 4 & 46 & 1.17 & 142 & 7898.3 & 142 & 3544.3 \\
\hline 5 & 62 & 0.70 & 222 & 12638.6 & 226 & 1732.3 \\
\hline 6 & 62 & 1.00 & 541 & 7669.0 & 102 & 25407.4 \\
\hline 7 & 56 & 0.65 & 154 & 22323.1 & 257 & 2776.9 \\
\hline 8 & 57 & 1.00 & 98 & 17385.0 & 206 & 8030.0 \\
\hline 9 & 62 & 0.70 & 101 & 26838.6 & 297 & 2634.3 \\
\hline 10 & 67 & 0.75 & 227 & 9097.3 & 113 & 2542.7 \\
\hline 11 & 69 & 0.77 & 173 & 7364.9 & 97 & 5037.7 \\
\hline 12 & 61 & 0.77 & 140 & 17002.6 & 223 & 2619.5 \\
\hline 13 & 63 & 0.72 & 183 & 4290.3 & 57 & 6486.1 \\
\hline 14 & 61 & 1.30 & 20 & 2314.6 & 35 & 835.0 \\
\hline 15 & 59 & 0.93 & 102 & 4146.2 & 67 & 2695.7 \\
\hline 16 & 61 & 0.87 & 128 & 2973.6 & 40 & 1985.1 \\
\hline 17 & 62 & 1.00 & 151 & 3396.0 & 47 & 1233.0 \\
\hline 18 & 65 & 1.03 & 277 & 7538.8 & 104 & 6128.2 \\
\hline 19 & 62 & 0.72 & 401 & 16966.7 & 257 & 5101.4 \\
\hline 20 & 68 & 1.08 & 112 & 2621.3 & 40 & 866.7 \\
\hline 21 & 67 & 0.58 & 114 & 4619.0 & 81 & 1524.1 \\
\hline 22 & 60 & 0.72 & 78 & 7013.9 & 92 & 695.8 \\
\hline 23 & 58 & 0.80 & 19 & 2988.8 & 38 & 258.8 \\
\hline 24 & 55 & 0.58 & 57 & 2462.1 & 43 & 491.4 \\
\hline 25 & 68 & 0.82 & 110 & 4573.2 & 62 & 704.9 \\
\hline 26 & 68 & 0.55 & 275 & 4310.9 & 64 & 3930.9 \\
\hline 27 & 53 & 0.75 & 99 & 13820.0 & 215 & 13917.3 \\
\hline 28 & 53 & 0.83 & 359 & 9721.7 & 146 & 1394.0 \\
\hline 29 & 57 & 0.62 & 179 & 12537.1 & 240 & 2293.5 \\
\hline 30 & 55 & 0.48 & 169 & 4512.5 & 54 & 2447.9 \\
\hline 31 & 57 & 0.58 & 76 & 3520.7 & 57 & 2334.5 \\
\hline 32 & 60 & 0.50 & 84 & 1688.0 & 24 & 618.0 \\
\hline 33 & 57 & 0.62 & 265 & 2766.1 & 42 & 2932.3 \\
\hline
\end{tabular}

Five species were identified as cartilaginous fishes, among those G. cemiculus and M. mustelus are of limited economic value. These fishes take part in IUCN Red List as $\mathrm{CR}$ and VU, respectively. All chondrichthyes was sorted as discard and they covered $11 \%$ of the total catch. Cartilaginous fish were estimated to $33 \%$ of the total discard catch biomass. Dasyatis pastinaca covered the largest part of the total discard catch biomass but was represented by low numbers in the total abundance. Yemişken et al. (2014) mentioned that the species is among the vast majority of the discard catch biomass with
Gymnura altavela in the area. Also, Yaglioglu et al. (2015) estimated that D. pastinaca constitutes $38 \%$ of the total elasmobranch biomass.

During the study period, 21 species $(31 \%)$ were determined as Red Sea immigrants. These species were estimated as $57.5 \%$ of the total teleost catch biomass and the rest of the catch consisted of the AtlantoMediterranean species. Özyurt et al. (2018) mentioned that $35 \%$ of the teleost species are Red Sea species and percentage of them is $75 \%$ in the total biomass. 
Table 2. The standardized values of the landed and discard catch as CPUEA (ind./h) and CPUEw $(\mathrm{g} / \mathrm{h})$ in the Iskenderun Bay. Status of the listed fishes were determined as D (Discard) and L (Landed) (Red Sea immigrants*; Cartilaginous ${ }^{++}$).

\begin{tabular}{|c|c|c|c|c|c|}
\hline Species & $\begin{array}{l}\text { Landed } \\
\left(\text { CPUE }_{A}\right)\end{array}$ & $\begin{array}{l}\text { Landed } \\
\text { (CPUE } w)\end{array}$ & $\begin{array}{l}\text { Discard } \\
\left(\text { CPUE }_{A}\right)\end{array}$ & $\begin{array}{l}\text { Discard } \\
\text { (CPUEw) }\end{array}$ & Status \\
\hline Apterichtus caecus (Linnaeus, 1758) & 0 & 0 & 6 & 37 & $\mathbf{D}$ \\
\hline Arnoglossus grohmanni (Bonaparte, 1837) & 0 & 0 & 5 & 13 & D \\
\hline Arnoglossus thori Kyle, 1913 & 0 & 0 & 149 & 644 & D \\
\hline Blennius ocellaris Linnaeus, 1758 & 0 & 0 & 5 & 59 & $\mathbf{D}$ \\
\hline Boops boops (Linnaeus, 1758) & 32 & 870 & 5 & 108 & $\mathbf{L}$ \\
\hline Bregmaceros nectabanus Whitley, 1941* & 0 & 0 & 1 & 2 & D \\
\hline Caranx rhonchus Geoffroy St. Hilaire, 1817 & 57 & 3536 & 43 & 1572 & $\mathbf{L}$ \\
\hline Cepola macrophthalma (Linnaeus, 1758) & 0 & 0 & 9 & 30 & $\mathbf{D}$ \\
\hline Champsodon nudivittis (Ogilby, 1895)* & 0 & 0 & 1478 & 13725 & D \\
\hline Chelidonichthys lastoviza (Bonnaterre, 1788) & 2 & 124 & 22 & 272 & $\mathbf{L}$ \\
\hline Chelidonichthys lucerna (Linnaeus, 1758) & 309 & 18396 & 17 & 3461 & $\mathbf{L}$ \\
\hline Chelon auratus (Risso, 1810) & 1 & 157 & 0 & 0 & $\mathbf{L}$ \\
\hline Citharus linguatula (Linnaeus, 1758) & 0 & 0 & 831 & 12368 & $\mathbf{D}$ \\
\hline Conger conger (Linnaeus, 1758) & 1 & 411 & 0 & 0 & $\mathbf{L}$ \\
\hline Cynoglossus sinusarabici (Chabanaud, 1931)* & 0 & 0 & 1 & 9 & $\mathbf{D}$ \\
\hline Dasyatis marmorata $\left(\right.$ Steindachner, 1892) ${ }^{++}$ & 0 & 0 & 1 & 230 & $\mathbf{D}$ \\
\hline Dasyatis pastinaca (Linnaeus, 1758) ${ }^{++}$ & 0 & 0 & 34 & 40168 & $\mathbf{D}$ \\
\hline Deltentosteus collonianus (Risso, 1820) & 0 & 0 & 6 & 17 & $\mathbf{D}$ \\
\hline Deltentosteus quadrimaculatus (Valenciennes, 1837) & 0 & 0 & 36 & 97 & $\mathbf{D}$ \\
\hline Diplodus annularis (Linnaeus, 1758) & 38 & 2039 & 0 & 0 & $\mathbf{L}$ \\
\hline Dussumieria elopsoides Bleeker, 1849* & 31 & 894 & 10 & 193 & $\mathbf{L}$ \\
\hline Echelus myrus (Linnaeus, 1758) & 0 & 0 & 1 & 131 & D \\
\hline Echeneis naucrates Linnaeus, 1758 & 0 & 0 & 1 & 30 & $\mathbf{D}$ \\
\hline Engraulis encrasicolus (Linnaeus, 1758) & 0 & 0 & 42 & 173 & D \\
\hline Epinephelus aeneus (Geoffroy St. Hilaire, 1817) & 2 & 135 & 0 & 0 & $\mathbf{L}$ \\
\hline Epinephelus costae (Steindachner, 1878) & 2 & 304 & 0 & 0 & $\mathbf{L}$ \\
\hline Equulites klunzingeri (Steindachner, 1898)* & 0 & 0 & 1681 & 19312 & $\mathbf{D}$ \\
\hline Etrumeus golanii DiBattista, Randall \& Bowen, 2012* & 2 & 146 & 0 & 0 & $\mathbf{L}$ \\
\hline Glaucostegus cemiculus (Geoffroy St. Hilaire, 1817) ${ }^{++}$ & 0 & 0 & 8 & 4951 & D \\
\hline Gobius niger Linnaeus, 1758 & 0 & 0 & 3 & 67 & D \\
\hline Gobius paganellus Linnaeus, 1758 & 0 & 0 & 1 & 8 & $\mathbf{D}$ \\
\hline Jaydia queketti (Gilchrist, 1903)* & 0 & 0 & 26 & 105 & D \\
\hline Jaydia smithi Kotthaus, 1970* & 0 & 0 & 49 & 381 & D \\
\hline Lagocephalus guentheri Miranda Ribeiro, 1915 & 0 & 0 & 40 & 1355 & $\mathbf{D}$ \\
\hline Lagocephalus suezensis Clark \& Gohar, 1953* & 0 & 0 & 35 & 795 & $\mathbf{D}$ \\
\hline Lepidotrigla cavillone (Lacepède, 1801) & 0 & 0 & 17 & 179 & D \\
\hline Lepidotrigla dieuzeidei Blanc \& Hureau, 1973 & 0 & 0 & 1 & 16 & D \\
\hline Merluccius merluccius (Linnaeus, 1758) & 9 & 268 & 1 & 16 & $\mathbf{L}$ \\
\hline
\end{tabular}


Table 2. Continued.

\begin{tabular}{|c|c|c|c|c|c|}
\hline Species & $\begin{array}{l}\text { Landed } \\
\left(\text { CPUE }_{\mathrm{A}}\right)\end{array}$ & $\begin{array}{l}\text { Landed } \\
\text { (CPUEw) }\end{array}$ & $\begin{array}{l}\text { Discard } \\
\left.\text { (CPUE }_{\mathbf{A}}\right)\end{array}$ & $\begin{array}{l}\text { Discard } \\
\text { (CPUEw) }\end{array}$ & Status \\
\hline Mullus barbatus Linnaeus, 1758 & 159 & 10800 & 4 & 1130 & $\mathbf{L}$ \\
\hline Mustelus mustelus (Linnaeus, 1758) & 0 & 0 & 2 & 750 & D \\
\hline Nemipterus randalli Russell, 1986* & 1187 & 62856 & 1117 & 22317 & $\mathbf{L}$ \\
\hline Ostorhinchus fasciatus (Shaw, 1790)* & 0 & 0 & 18 & 40 & D \\
\hline Oxyurichthys petersii (Klunzinger 1871)* & 0 & 0 & 175 & 2673 & D \\
\hline Pagellus acarne (Risso, 1827) & 168 & 5057 & 10 & 1032 & $\mathbf{L}$ \\
\hline Pagellus erythrinus (Linnaeus, 1758) & 352 & 19220 & 13 & 677 & $\mathbf{L}$ \\
\hline Pelates quadrilineatus (Bloch, 1790)* & 8 & 209 & 2 & 29 & $\mathbf{L}$ \\
\hline Pomatomus saltatrix (Linnaeus, 1766) & 15 & 1767 & 0 & 0 & $\mathbf{L}$ \\
\hline Raja miraletus Linnaeus, $1758^{++}$ & 0 & 0 & 1 & 191 & D \\
\hline Sardina pilchardus (Walbaum, 1792) & 8 & 271 & 0 & 0 & $\mathbf{L}$ \\
\hline Saurida lessepsianus Russell, Golani \& Tikochinski, 2015* & 822 & 85731 & 112 & 7575 & $\mathbf{L}$ \\
\hline Scomber colias Gmelin, 1789 & 1 & 33 & 0 & 0 & $\mathbf{L}$ \\
\hline Serranus hepatus (Linnaeus, 1758) & 0 & 0 & 100 & 1395 & D \\
\hline Siganus rivulatus Forsskål \& Niebuhr, 1775* & 2 & 54 & 0 & 0 & $\mathbf{L}$ \\
\hline Solea solea (Linnaeus, 1758) & 50 & 6055 & 33 & 1676 & $\mathbf{L}$ \\
\hline Sparus aurata Linnaeus, 1758 & 773 & 65683 & 0 & 0 & $\mathbf{L}$ \\
\hline Sphyraena chrysotaenia Klunzinger, 1884* & 1 & 156 & 0 & 0 & $\mathbf{L}$ \\
\hline Spicara smaris (Linnaeus, 1758) & 0 & 0 & 4 & 47 & D \\
\hline Synodus saurus (Linnaeus, 1758) & 2 & 103 & 0 & 0 & $\mathbf{L}$ \\
\hline Torquigener flavimaculosus Hardy \& Randall, 1983* & 0 & 0 & 1 & 27 & D \\
\hline Trachinus draco Linnaeus, 1758 & 0 & 0 & 6 & 343 & D \\
\hline Trachurus indicus Nekrasov, 1966* & 28 & 1542 & 3 & 46 & $\mathbf{L}$ \\
\hline Trachurus mediterraneus (Steindachner, 1868) & 2 & 16 & 0 & 0 & $\mathbf{L}$ \\
\hline Trachurus trachurus (Linnaeus, 1758) & 3 & 40 & 87 & 294 & $\mathbf{L}$ \\
\hline Trichiurus lepturus Linnaeus, 1758 & 27 & 2513 & 3 & 25 & $\mathbf{L}$ \\
\hline Upeneus moluccensis (Bleeker, 1855)* & 50 & 653 & 99 & 570 & $\mathbf{L}$ \\
\hline Upeneus pori Ben-Tuvia \& Golani, 1989* & 4 & 81 & 0 & 0 & $\mathbf{L}$ \\
\hline Zeus faber Linnaeus, 1758 & 0 & 0 & 3 & 6 & D \\
\hline Total & 4148 & 290120 & 6358 & 141367 & \\
\hline
\end{tabular}

Among Erythrean species, Saurida lessepsianus and Nemipterus randalli were the most important species that were obtained in the trawl fishery (Fig. 2). Also, these species constitute $41 \%$ of the landed catch. Gücü et al. (1994) estimated that about $30 \%$ of the Teleost catch from the bay belonged to $S$. lessepsianus. Dasyatis pastinaca, Equulites klunzingeri and $N$. randalli constituted $58 \%$ of the discard catch biomass while $E$. klunzingeri, Champsodon nudivittis and $N$. randalli were included in the abundance of discard catch with a percentage of $68 \%$.
Conger conger, Diplodus annularis, Epinephelus aeneus, E. costae, Etrumeus teres, Chelon auratus, Pomatomus saltatrix, Sardina pilchardus, Scomber colias, Siganus rivulatus, Sparus aurata, Sphyraena chrysotaenia, Synodus saurus, Trachurus mediterraneus and Upeneus pori were not found in the discard catch. The local fishermen tend to evaluate all sizes of E. aeneus, E. costae and S. aurata in the landed catch. The intense trawl fisheries activity is the main threat for these fishes in the bay (Fig. 3). 


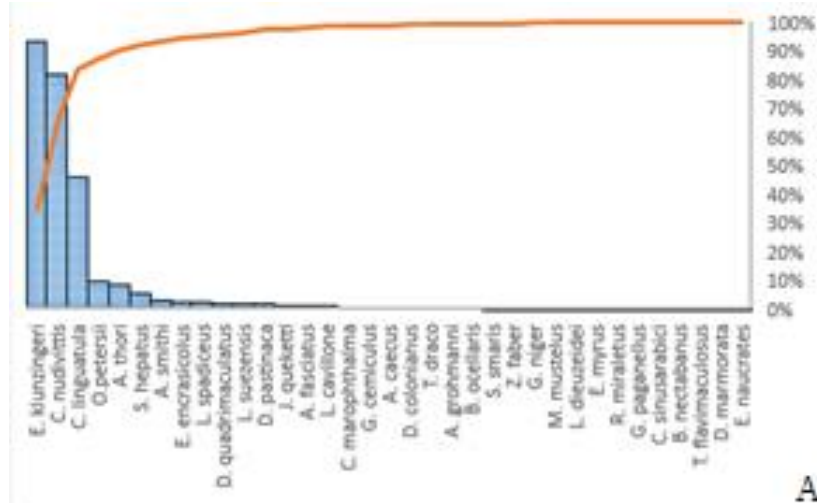

A

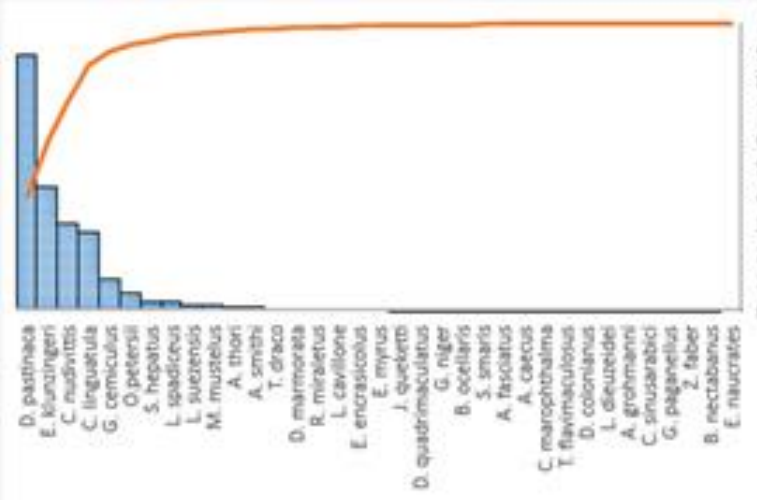

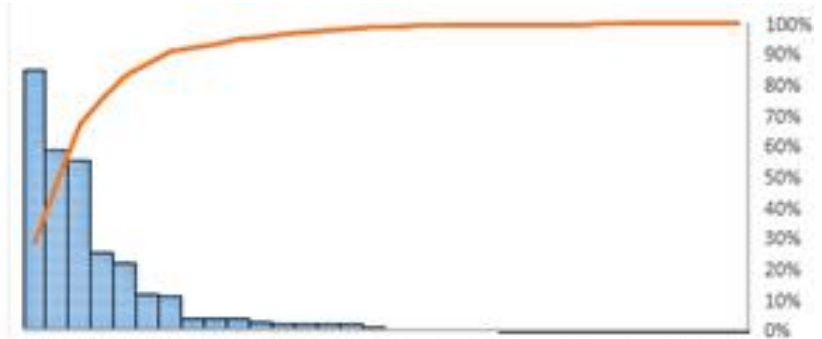

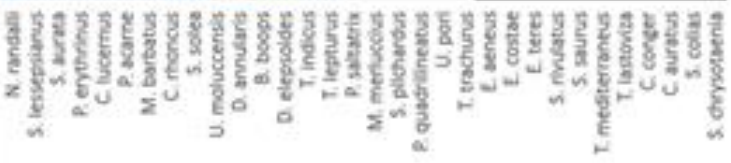

B

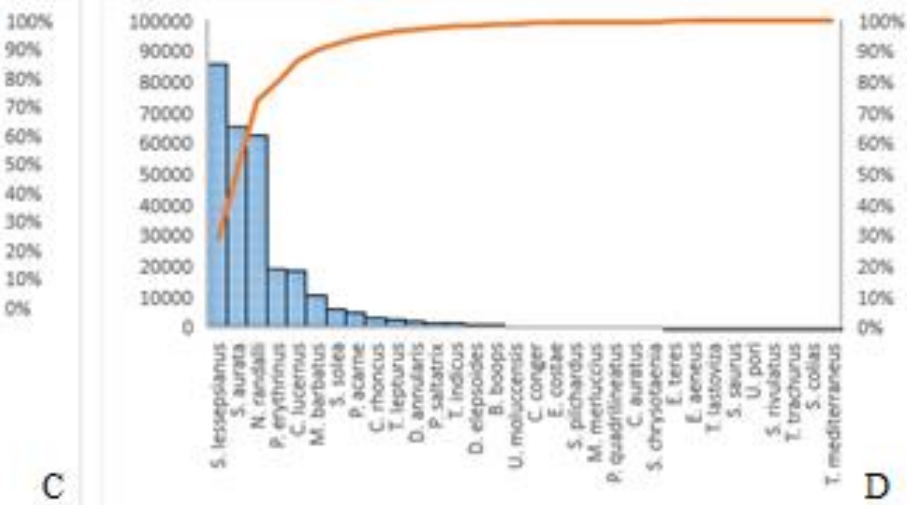

Fig. 2. The standardized values of the catch in the Iskenderun Bay; A) CPUEA of the discard catch, B) CPUEw of the discard catch, C) $\mathrm{CPUE}_{\mathrm{A}}$ of the landed catch, D) CPUEW of the landed catch.

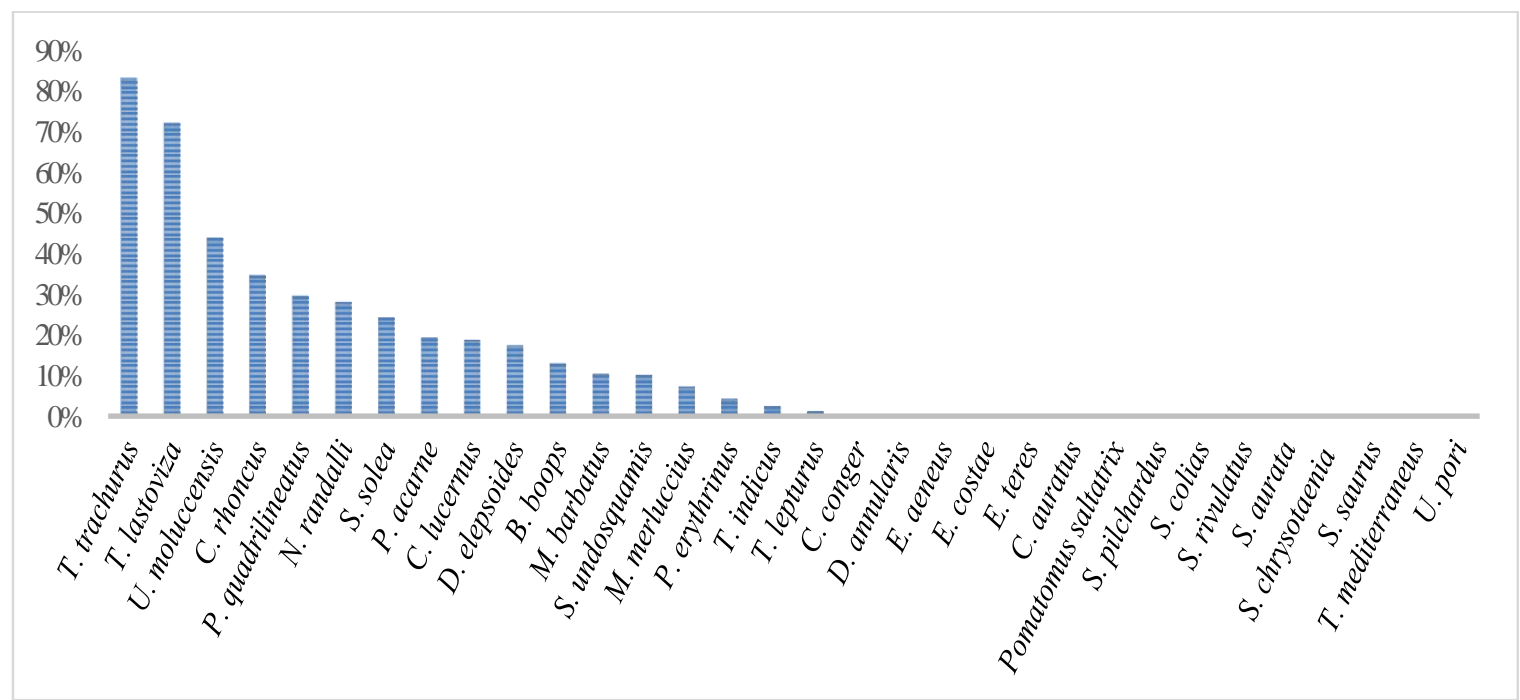

Fig. 3. The discard rates of fishes in the landed catch in the Iskenderun Bay at 2012-2013 fishing period.

In the Northeastern Levantine Sea, the catch and discard of the trawl fishery have a trend to decrease towards the end of the fishing season. The biomass value of seasonal catch declines sharply in the January-February period (Yemişken et al. 2014, Gökçe et al. 2016). The total catch biomass estimated in April was about 2 times higher than the February (Fig. 4). The depth range differences between the studies may have caused this mismatch.
Considering the values of trawl fishery of the bay, it appeared that most of the discard biomass consisted of chondrichthyes species that feed on carcasses formed as a result of intense fishing activity. Besides, two of the three species ( $S$. lessepsianus and $N$. randalli) occupying the majority of the landed biomass belong to the Red Sea immigrants, indicating that the existence of these species in the region has irreversible effects. The dispersal success of the Red Sea immigrants plays a significant role 
in the trawl fisheries and these species should be monitored with long-running studies.

Studies on discard catches are important in terms of fisheries management, especially for multispecies trawl fisheries. Additional comprehensive studies and long-term monitoring are needed in order to understand the population dynamics and to detect ultimate changes in the target area. Moreover, there is no study to reduce fishing pressure on the fish stocks, except Gücü (2012) who revealed that regulations of depth and fishing period had a

\section{References}

1. Bayhan, K.Y., Çiçek, E., Ünlüer, T. \& Akkaya, M. 2006. Guneydoğu Marmara'da Algarna ile Karides Avcılığında Av Kompozisyonu ve Hedef D1şı Av. Ege Universitesi Su Urunleri Fakultesi Yayınlarl, 23(3-4): 277-283.

2. Bordalo-Machado, P. 2006. Fishing effort analysis and its potential to evaluate stock size. Reviews in Fisheries Science, 14: 369-393.

3. Demirci, A. 2003. Non Target Demersal Species Inhabiting Iskenderun Bay and Their Biomass Estimation. Msc. Thesis, Mustafa Kemal Üniversitesi, Antakya, Turkey, 40 pp.

4. D’onghia, G., Carlucci, R., Maiorano, P. \& Panza, M. 2003. Discards from deep-water bottom trawling in the EasternCentral Mediterranean Sea and effects of mesh size changes. Journal of Northwestern Atlantic Fisheries Science, 31: 245-261.

5. Gökçe, G. \& Metin, C. 2006. Balıkçılıkta hedef dışı Av sorunu uzerine bir inceleme. Ege Universitesi Su Urunleri Dergisi, 23(3-4): 457-462.

6. Gökçe, G., Saygu, İ. \& Eryaşar, A.R. 2016. Catch composition of trawl fisheries in Mersin Bay with emphasis on catch biodiversity. Turkish Journal of Zoology, 40: 522533. https://doi:10.3906/zoo-1505-35

7. Gücü, A.C., Bingel, F., Avşar, D. \& Uysal, N. 1994. Distribution and Occurrence of Red Sea Fish at The Turkish Mediterranean Coast-Northern Cilician Basin. Acta Adriatica, 34(1/2): 103-113.

8. Gücü, A.C., Ok, M. \& Sakınan, S. 2010. Sub Regional Technical Meeting on the Lesepsian Migration and Its Impact on Eastern Mediterranean Fishery, Past and Present of Fish Fauna in the NE Levant Sea and Factor Facilitating the Colonization by Lesepsian Fishes. FAO Eastmed Working Document, 7-9 December 2010 Nicosia, 88-108.

9. Gücü, A.C. 2012. Impact of depth and season on the demersal trawl Discard. Turkish Journal of Fisheries and Aquatic Sciences, 12: 817-830.

10. Karpuz, E. \& Sakalli, A., 2019. Investigation of the Effect of Climate Change Affecting Sea Surface Temperature Mean between 1999 and 2012 on the Maritime Trade in the Gulf of Iskenderun. Natural and Engineering Sciences, 4(1): 55-64.

11. Kınacıgil, T.H., Çıra, E. \& İlkyaz, T.A. 1999a. Balıç̧ılıkta Hedeflenmeden Avlanan Turler Sorunu. Ege Universitesi Su Urunleri Dergisi, 16(3-4): 437-444.

12. Kınacıgil, H.T., Çıra, E. \& İlkyaz, A.T. 1999b. A Preliminary Study on the Shrimp Trawling Bycatch In Tasucu Bay (Northeastern Mediterranean). Journal of Fisheries and Aquatic Science, 16(1-2): 99-105. positive effect to mitigate discard rates in the north-eastern Levantine Sea. Advanced studies should be encouraged in the area which has significant demersal resources that are under the pressure of intense fisheries activities.

\section{Acknowledgement}

This study was funded by the Scientific Research Projects Coordination Unit of Istanbul University (Project number: 27457). The author thanks Nur Bikem KESICI for contributions on an earlier version of the manuscript.

13. Machias, A., Vassilopoulou, V., Vatsos, D., Bekas, P., Kallianiotis, A., Papaconstantinou, C. \& Tsimenides, N. 2001. Bottom trawl discards in the northeastern Mediterranean Sea. Fisheries Research, 53: 181-195.

14. Morgan, A.C. \& Burgess, G.H. 2005. Fishery-dependent sampling: total catch, effort and catch composition. pp. 182-215. In J. Musick and R.Bonfil, (Eds) Management techniques for elasmobranch fisheries. Food and Agricultural Organization of the United Nations, Rome, $251 \mathrm{pp}$.

15. Özyurt C.E., Perker M., Kiyağa V.B., Mavruk S. \& Kayaalp G. 2018. Biomass of some lessepsian fish species in the soft bottoms of Iskenderun Bay (Northeast Mediterranean). Review of Hydrobiology, 1: 23-39.

16. Pérez Roda, M.A., Gilman, E., Huntington, T., Kennelly, S.J., Suuronen, P., Chaloupka, M. \& Medley, P. 2019. A third assessment of global marine fisheries discards. FAO Fisheries and Aquaculture Technical Paper No. 633. Rome, FAO. 78 pp.

17. Soykan, O., Kınacıgil, T.H. \& Tosunoğlu, Z. 2006. Taşucu Körfezi (Doğu Akdeniz) Karides Trollerinde Hedefdışı Av. Ege Universitesi Su Urunleri Fakultesi Yayınları, 23(1-2): 67-70.

18. Terbıyık Kurt, T. 2018. Contribution and acclimatization of the swarming tropical copepod Dioithona oculata (Farran, 1913) in a Mediterranean coastal ecosystem. Turkish Journal of Zoology, 42: 567-577. https://doi:10.3906/zoo$1802-42$

19. Weissenberger, J. 2014. Fisheries: why technical measures matter. In-depth. Analysis. Brussels: European Parliamentary Research Service.

20. Yağlığlu, D., Deniz, T., Gürlek, M., Ergüden, D. \& Turan, C. 2015. Elasmobranch bycatch in a bottom trawl fishery in the Iskenderun Bay, northeastern Mediterranean. Cahiers de Biologie Marine, 56(3): 237-243.

21. Yazıcı, F.M., İşmen, A., Altınağaç, U. \& Ayaz, A. 2006. Marmara Deniz'inde Karides Algarnasının Av Kompozisyonu ve Hedeflenmeyen Av üzerine Bir Çalışma. Ege Universitesi Su Urunleri Fakultesi Yayınlarl, 23(3-4): 269-275.

22. Yemişken, E., Dalyan, C. \& Eryılmaz, L. 2014. Catch and discard fish species of trawl fisheries in the iskenderun Bay (North-eastern Mediterranean) with emphasis on lessepsian and chondricthyan species. Mediterranean Marine Science, 15(2): 380-389. https://doi.org/10.12681/mms.538

23. Zeller, D, Cashion, T, Palomares, M. \& Pauly, D. 2018. Global marine fisheries discards: A synthesis of reconstructed data. Fish and Fisheries, 19: 30-39. https://doi.org/10.1111/faf.12233 